Kasperska Anastasiia,

Master's student of "Civil Service",

Donetsk State University of Management,

Deputy Head of the Legal Department Artyomovsk City Council

Khaletska Alina,

Doctor's degree in Public Administration, Professor,

Volyn Institute of Economics and Management, Lutsk

\title{
CHALLENGES OF STAFF SELECTION PROCEDURES IN THE LOCAL GOVERNMENT
}

The article examines modern requirements of Ukrainian legislation to the staff selection procedure in the local governments. The paper depicts the features of checks on candidates for local government focusing on the legislation on purifying government and fight corruption. The paper explores tests facing candidates for the posts in the local government, considering the legislation on the clarification of the power and the fight against corruption. The research determines the current problems faced by personnel officers at the stage of hiring foreign candidates and conversing public servants or the officials equated to them. The paper suggests the ways to improve the personnel selection for serving in local self-governments.

Keywords: human resources component; local government; lustration; the fight against corruption.

(C) Касперська Анастасія, Халецька Аліна

Надійшла до редакції 27.04.2015

\section{УДК 314.72}

\section{КОРОБКА ІРИНА,}

слухач магістратури спечіальності "Державна служба"

Донецького державного університету управління,

заступник начальника відділу бухгалтерського обліку Маріупольської міської ради

ПАВЛЮК ВАЛЕРІЙ,

кандидат наук з державного управління, доцент, дочент кафедри державного управління та управління освітою Київського університету ім. Бориса Гринченко, м. Київ

\section{ОРГАНІЗАЦІЙНО-ПРАВОВІ ЗАСАДИ СОЦІАЛЬНОГО ЗАХИСТУ ПЕРЕСЕЛЕНЦІВ (ВНУТРІШНЬО ПЕРЕМІЩЕНИХ ОСІБ) ЯК ОСНОВА РЕАЛІЗАЦІї СОЦІАЛЬНОÏ ПОЛІТИКИ ДЕРЖАВИ}

У статті проаналізовано нові тенденції соціальної політики, спрямовані на підтримку внутрішніх переселенців в Україні. Уточнюються мінімальні стандарти соціальної допомоги для даної категорії громадян та визначаються основні принципи соціальної підтримки. Розглянуто сутність соціальної політики при наданні адресної допомоги та зміст понять "внутрішньо переміщена особа", "адресна допомога". Показано роль та направленість державної соціальної підтримки внутрішньо переміщеним особам.

Ключові слова: соціальна політика; внутрішньо переміщена особа; адресна допомога.

Постановка проблеми і стан її вивчення. В узагальненому вигляді діяльність держави із задоволення соціальних потреб людей визначається як її соціальна політика. У період проведення антитерористичної операції держава має вирішувати вчасно ряд проблемних питань, що не було враховано раніше при визначенні соціальної політики, та перекроювати державний бюджет для вдосконалення соціальної політики, а також підтримки переселенців із зони АТО.

Актуальність статті зумовлена тим, що на загальнонаціональному рівні соціальна політика $€$ одним з найважливіших напрямів внутрішньої політики держави, 
пов'язаним з відтворенням соціальних ресурсів і забезпеченням як стабільності соціальної системи, так і динамічності їі розвитку.

Наукове опрацювання проблем реєстрації та обліку внутрішньо переміщених осіб тільки починається, про що свідчать, наприклад, публікації [1-2], але в основному ця проблема розглядається зацікавленими в ії̈ вирішенні офіційними сторонами, наприклад, Кабінетом Міністрів України, Федерацією профспілок України, громадськими організаціями.

Надання соціальної допомоги є виконанням соціальної функції державного управління та дієвим інструментом підтримки і запевнення людей в тому, що держава в таких складних умовах, в стані війни, опікується ними.

Мета статті - визначити проблемні аспекти надання адресної соціальної допомоги внутрішнім переселенцям та запропонувати шляхи їх вирішення.

Виклад основного матеріалу. Внутрішньо переміщеною особою $є$ громадянин України, який постійно проживає в Україні, якого змусили або який самостійно покинув своє місце проживання у результаті або з метою уникнення негативних наслідків збройного конфлікту, тимчасової окупації, повсюдних проявів насильства, масових порушень прав людини та надзвичайних ситуацій природного чи техногенного характеру [3]

Адресна допомога - це форма соціальної допомоги, яку держава надає персонально малозабезпеченим працездатним чи непрацездатним громадянам, враховуючи потреби конкретної людини.

Відповідно до ст. 3 Конституції України: "Людина, ї̈ життя і здоров'я, честь і гідність, недоторканність і безпека визнаються в Україні найвищою соціальною цінністю" [4].

3 метою посилення соціального захисту осіб, які переміщуються з тимчасово окупованої території України та місць проведення антитерористичної операції, було підписано та прийнято надзвичайно важливі закони та постанови щодо визначення внутрішньо переміщених осіб, надання щомісячної адресної допомоги переселенцям та про їх облік:

- Закон України "Про забезпечення прав і свобод внутрішньо переміщених осіб" від 20.10.2014 за № 1706-VII;

- Закон України "Про забезпечення прав і свобод громадян та правовий режим на тимчасово окупованій території України" від 15.04.2014 № 1207-VII;

- Постанова Кабінету Міністрів України від 01.10. 2014 р. № 509 "Про облік осіб, які переміщуються 3 тимчасово окупованої території України та районів проведення антитерористичної операції";

- Постанова Кабінету Міністрів України від 01.10.2014 № 505 "Про надання щомісячної адресної допомоги особам, які переміщуються з тимчасово окупованої території України та районів проведення антитерористичної операції, для покриття витрат на проживання, в тому числі на оплату житлово-комунальних послуг";

Постанова Кабміну від 5 листопада 2014 за №637 "Про здійснення соціальних виплат особам, які переміщаються з тимчасово окупованої території України і районів проведення антитерористичної операції";

- Розпорядження Кабінету Міністрів України від 7 листопада 2014 р. № 1085-р "Про затвердження переліку населених пунктів, на території яких органи державної влади тимчасово не здійснюють або здійснюють не в повному обсязі свої повноваження".
Механізм видачі довідки про взяття на облік особи, яка переміщується з тимчасово окупованої території України або району проведення антитерористичної операції регулюється Постановою КМУ 01.10.2014р. № 509 "Про облік осіб, які переміщуються з тимчасово окупованої території України та районів проведення антитерористичної операції".

Довідка є документом, який видається громадянам України, іноземцям та особам без громадянства, які постійно проживають на території України і переміщуються з тимчасово окупованої території України та районів проведення антитерористичної операції або змушені були покинути своє постійне місце проживання в населених пунктах, на території яких органи державної влади тимчасово не здійснюють або здійснюють не в повному обсязі свої повноваження, і перемістилися в населені пункти, на території яких органи державної влади здійснюють свої повноваження в повному обсязі [5].

Слід зазначити, що довідка про взяття на облік потрібна переселенцям для отримання за фактичним місцем проживання пенсій, державних стипендій, інших видів соціальної допомоги і компенсацій, матеріального забезпечення, надання соціальних послуг за рахунок засобів державного бюджету і фондів загальнообов'язкового державного соціального страхування.

Довідка про взяття на облік внутрішньо переміщеної особи видається структурним підрозділом місцевої державної адміністрації з питань соціального захисту населення в день подання заяви, підписується та засвідчується уповноваженою посадовою особою цього структурного підрозділу без сплати будь-яких платежів та зборів, включаючи як першу видачу такої довідки, так і в разі повторної її видачі у випадку втрати, пошкодження або з метою продовження ії дії [4]. Термін дії такої довідки становить шість місяців з моменту її видачі, див. п. 8 Закону України "Про забезпечення прав і свобод внутрішньо переміщених осіб" від 20.10.2014 за №1706-VII [3].

Після прийняття рішень на державному рівні щодо припинення фрінансування по виплаті пенсій та соціальних допомог на тих територіях, де влада не здійснюе свої повноваження та прийняття відповідних постанов, громадяни почали звертатися до управлінь соціального захисту населення у тих районах, куди перемістилися для отримання довідок і можливості отримання соціальної підтримки від держави.

На виконання Постанови № 509 частини 6 у день подання заяви безоплатно видається довідка за встановленою формою, яка роздруковується на папері формату A4 і підписується посадовою особою уповноваженого органу та скріплюється печаткою відповідного уповноваженого органу [5]. В окремих випадках деякі управління соціального захисту не виконували зазначений пункт і довідки видавалися через два або три дні після звернень громадян.

У зв'язку з постійною міграцією осіб-переселенців виникає проблема щодо "задвоєння" даних про взяття на облік по всій Україні. На виконання Постанови № 509 частини 9 у разі зміни місця тимчасового перебування заявник звертається за видачею довідки до іншого уповноваженого органу, а раніше видана довідка вилучається, про що вносяться відповідні зміни до Єдиної інформаційної бази даних про взятих на облік осіб, які переміщуються з тимчасово окупованої території України та районів проведення антитерористичної операції [Там само]. 
Наприклад, зареєстрована особа, яка переїхала на проживання у інше місто, повинна звернутися до УСЗН за місцем тимчасового проживання, написати нову заяву, отримати нову довідку, а стару вилучають спеціалісти соціального захисту та повідомляють за попереднім місцем реєстрації.

Проблеми з опрацювання цього переміщення виникають у зв'язку зі строками і відсутністю всеукраїнської бази переміщених осіб. Взагалі, відповідно до Постанови № 509 частини 5 з метою обліку осіб, які переміщуються, уповноважений орган веде Єдину інформаційну базу даних про взятих на облік осіб, які переміщуються $з$ тимчасово окупованої території України та районів проведення антитерористичної операції, держателем якої є Мінсоцполітики, до якої включається інформація про особу, яка переміщується, зазначена у поданій заяві про взяття на облік відповідно до пункту 3 цього Порядку, а також дата видачі довідки, назва уповноваженого органу, що їі видав, та інформація про задоволення заявлених потреб, надані послуги (виплати) [4]. Але кожне управління соціального захисту має свою базу осіб-переселенців, тримачем якої $є$ Мінсоцполітики і тільки раз на місяць усі бази надаються до міністерства, яке опрацьовує дані щодо обліку переселенців і розсилає виявлені задвоєні дані при співпадінні імен, кодів платників податків тощо. Великого пласта роботи щодо обробляння подвійних реєстрацій можна було уникнути за умови, якщо би база про взяття на облік переселенців була всеукраїнська і працювала у режимі он-лайн по всій Україні.

Дана проблема буде і надалі наростати у громадян з зони проведення АTO, що мігрують у пошуку місць для проживання та роботи. Це пов'язано з тим, що у зоні ATO, в тих місцях, де українська влада здійснює свої повноваження, йде повний спад економіки та закриття виробничих потужностей.

Проблемним є й залишається питання взяття на облік осіб-переселенців у зоні проведення АТО. Зона ATO залишається незмінною і визначена наказом СБУ - антитерористичним центром № 33/6/а від 7 жовтня 2014 р. "Про визначення районів проведення антитерористичної операції і терміни ії̈ проведення", де чітко вказано, що це всі без винятку Луганська та Донецька області. І підконтрольні владі міста та райони, які розташовані на території зони проведення АТО, мають також реєструвати переміщених осіб.

Такі райони були визначені розпорядженням КМУ від 7 листопада 2014 р. № 1085-р "Про затвердження переліку населених пунктів, на території яких органи державної влади тимчасово не здійснюють або здійснюють не в повному обсязі свої повноваження", але починаючи з цієї дати зміст даного розпорядження змінювався щотижня, внесення змін до даного розпорядження не відбувалося у зв'язку з чим особам-переселенцям, які хотіли зареєструватися у зоні проведення АТО на підконтрольних владі територіях відмовляли щодо реєстрації та видачи довідки у зв'язку з відсутністю даного населеного пункту у даному переліку. На сьогодні ситуація стабілізувалася, були внесені необхідні зміни щодо визначення населених пунктів не тільки на яких влада тимчасово не здійснює свої повноваження, але й ті, які знаходяться у зоні зіткнення. За межами зони проведення АТО (Донецької і Луганської областей) органи соціального захисту керувалися тільки наказом СБУ № 33/6/а від 7 жовтня 2014 р.

Територіальний підрозділ Державної міграційної служби у триденний термін після повідомлення осо- бою, яка переміщується, про фактичне місце проживання проводить перевірку наведених у довідці відповідних відомостей, проставляє у разі підтвердження таких відомостей на зворотному боці довідки відмітку про реєстрацію місця проживання осіб, зазначених у довідці, та щодня подає в електронній формі уповноваженому органові відповідну інформацію. Довідка не $є$ дійсною без проставлення на її зворотному боці зазначеної відмітки.

Відповідно до Постанови Кабінету Міністрів України від 01.10.2014 № 505 "Про надання щомісячної адресної допомоги особам, які переміщуються з тимчасово окупованої території України та районів проведення антитерористичної операції, для покриття витрат на проживання, в тому числі на оплату житлово-комунальних послуг" запроваджено щомісячну адресну допомогу переселенцям для покриття витрат на проживання, у тому числі на оплату житлово-комунальних послуг [6].

Грошова допомога надається громадянам України, іноземцям та особам без громадянства, які постійно проживають на території України і переміщуються 3 тимчасово окупованої території України та районів проведення антитерористичної операції, а також стоять на обліку в органах соціального захисту населення. Призначення та виплату грошової допомоги здійснюють органи соціального захисту населення за фрактичним місцем проживання (перебування) за заявою уповноваженого представника сім'ї. Грошова допомога призначається 3 дня звернення та виплачується терміном не більше ніж шість місяців. Грошова допомога надається у таких розмірах:

- для непрацездатних осіб (пенсіонери, інваліди, діти) - 884 гривні на одну особу (члена сім'ї);

- для працездатних осіб - 442 гривні на одну особу (члена сім'ї).

Загальна сума допомоги на сім'ю розраховується як сума розмірів допомоги на кожного члена сім'ї та не може перевищувати 2400 гривень. Перелік документів для призначення грошової допомоги:

- заява;

- копія свідоцтва про одруження;

- копії свідоцтв про народження дітей;

- письмова згода довільної форми про виплату грошової допомоги уповноваженому представнику сім'ї від інших членів сім'ї;

- згода на обробку персональних даних.

Грошова допомога перераховується органом соціального захисту населення на рахунок в установі уповноваженого банку. Особам працездатного віку допомога призначається на два місяці. Для одержання допомоги у встановлених розмірах на наступний період особи працездатного віку мають працевлаштуватися, в тому числі за сприяння державної служби зайнятості.

Якщо працездатний член сім'ї протягом двох місяців не працевлаштувався, або перебуває у трудових відносинах з роботодавцями на тимчасово окупованій території України чи в районах проведення антитерористичної операції і фактично не працює, розмір допомоги для цих осіб на наступні два місяці зменшується на 50\%, а на наступний період - припиняється.

Грошова допомога не призначається у разі, коли:

- будь-хто з членів сім'ї має у власності житлове приміщення, розташоване в регіонах, інших ніж тимчасово окупована територія України та райони проведення антитерористичної операції;

- у володінні сім'ї $є$ два або більше транспортних засобів (механізмів), що підлягають державній реєст- 
рації та обліку в Державтоінспекції (автобусів, вантажних та легкових автомобілів). При цьому не враховуються транспортні засоби, одержані чи придбані на пільгових умовах через уповноважені органи, а також транспортні засоби вітчизняного виробництва, які перебувають в експлуатації протягом більш як 10 років з дати випуску, та інші транспортні засоби, що перебувають в експлуатації протягом більш як 15 років з дати випуску;

- будь-хто з членів сім'ї має на депозитному банківському рахунку кошти у сумі, що перевищує 10-кратний розмір прожиткового мінімуму, встановленого для працездатних осіб [Там само].

Органи соціального захисту при призначенні установленою державою соціальної підтримки зіткнулися 3 недобросовісністю громадян. При заповнені заяв щодо отримання відповідної допомоги особи з числа переселенців приховували, що мають у володінні більш двох транспортних засобів або житло поза межами проведення АТО. Мають місце випадки, коли громадяни реєструвалися у кількох населених пунктах, як переміщені особи та подавали заяви щодо виплати адресної допомоги.

Але для багатьох адресна допомога стала одним із важливих фракторів підтримки у межах проведення соціальної політики державою та мінімальним соціальним стандартом для виживання у таких обставинах.

Проблемне питання при наданні адресної допомоги - це стабільність та строки фінансування органів соціального захисту населення відповідного напрямку видатків. Відповідно до п.8 порядку надання щомісячної адресної допомоги особам, структурні підрозділи соціального захисту подають щомісяця до 10 та 20 числа заявки про потребу в коштах на виплату грошової допомоги структурним підрозділам з питань соціального захисту населення обласних, Київської міської держадміністрацій, які відповідно до п. 9 після надходження зазначених у пункті 8 заявок про потребу в коштах на виплату грошової допомоги та коштів державного бюджету не пізніше трьох робочих днів Мінсоцполітики перераховує відповідні кошти структурним підрозділам з питань соціального захисту населення обласних, Київської міської держадміністрацій [Там само]

Але терміни фрінансування не завжди витримуються: так, у кінці лютого 2015 року було профрінансовано адресну допомогу за січень та лютий 2015, що призводить до напруги в суспільстві і, як наслідок, до збільшення звернень громадян на урядову лінію зі скаргами про затримки виплати допомоги, яку вони бачать тільки в районних управліннях соціального захисту і на пояснення щодо неотримання на розрахункові рахунки фінансування громадяни не вірять.

При опрацюванні даного питання можна прийти до висновку, що у зв'язку з проведенням АТО питання щодо обліку вимушених переселенців та надання адресної допомоги має велику актуальність.

Низка проблемних питань постала при здійсненні обліку вимушених переселенців та виплати адресної допомоги у органів соціального захисту на місцевому рівні:

- зловживання особами з числа вимушених переселенців своїм становищем та надання завідомо неправдивої інформації щодо обліку у інших районах, наявність більш як двох засобів автомобільного транспорту, наявність другого житла поза межами АTO, що тягне за собою переплату даного виду допомоги;

- у разі звільнення з роботи особи, які отримують адресну допомогу, не повідомляють орган соціального захисту населення про відповідні зміни, що призводить до зайвих нарахувань допомоги;
- відсутність чітких законодавчо прийнятих рішень щодо обліку осіб, як вимушених переселенців, якщо в паспорті стоїть штамп про зняття особи з реєстрації у зоні проведення АТО, як брати на облік?

- відсутність однієї он-лайн загальноукраїнської бази для реєстрації осіб з числа вимушених переселенців, яка мала би працювати за допомогою мережі Інтернет та звела б до мінімуму здвоєння даних при здійсненні реєстрації і, як наслідок, виключила шахрайство з боку отримувачів адресної допомоги.

\section{Висновки}

Роль та направленість державної соціальної підтримки внутрішньо переміщеним особам сьогодні $\epsilon$ одним із пріоритетних напрямків державної соціальної політики.

Державна соціальна підтримка переміщених осіб має здійснюватися для адаптації громадян у нових умовах існування, щоб кожен громадянин у період проведення АТО розумів, що соціальні гарантії держави діють не залежно від того, де він буде знаходитися. Суспільство має зрозуміти, що держава підтримує, а не забезпечує повністю, і кожен також має працювати на користь держави.

Проблеми ж, що виникають під час надання соціальної допомоги та здійснення процедури реєстрації внутрішньо переміщених осіб, необхідно вирішувати шляхом удосконалення послідовності здійснення відповідних процесів, уніфікації електронної бази (єдиного реєстру) певної категорії громадян, а також опрацювання методики термінового узгодження невідповідностей, що виникають в роботі соціальних служб.

\section{ЛПЕРАТУРА}

1. Войналович І. А. Вимушені переселенці: зарубіжний досвід, стан і реалізація їх прав в Україні / І. А. Войналович, М. О. Кримова, Л. В. Щетініна // Соціально-трудові відносини: теорія та практика : зб. наук. пр. / М-во освіти і науки України, Держ. ВНЗ "Київ. нац. екон. ун-т ім. Вадима Гетьмана", Ін-т соціально-трудових відносин ; [редкол.: А. М. Колот (голова) та ін.]. - К. : КНЕУ, 2014. - № 2 (8). - С. 250-257.

2. Костюк Б. Виклик для держави і суспільства: вимушені переселенці з Криму [Електронний ресурс] / Б. Костюк. - Режим доступу : http://ua.krymr.com.

3. Про забезпечення прав і свобод внутрішньо переміщених осіб : Закон України від 20.10.2014 за №1706-VII [Електронний ресурс]. - Режим доступу : http://zakon4.rada.gov.ua/ laws/show/1706-18.

4. Конституція України [Електронний ресурс]. - Режим доступу : http://zakon4.rada.gov.ua/laws/show/254\%D0\%BA/96$\% \mathrm{D} 0 \% \mathrm{~B} 2 \% \mathrm{D} 1 \% 80$.

5. Про облік осіб, які переміщуються з тимчасово окупованої території України та районів проведення антитерористичної операції : Постанова Кабінету Міністрів України від 01.10.2014 p. № 509 [Електронний ресурс]. - Режим доступу : http://zakon4.rada.gov.ua/laws/show/509-2014-\%D0\%BF.

6. Про надання щомісячної адресної допомоги особам, які переміщуються з тимчасово окупованої території України та районів проведення антитерористичної операції, для покриття витрат на проживання, в тому числі на оплату житловокомунальних послуг : Постанови Кабінету Міністрів України від 01.10.2014 № 505 [Електронний ресурс]. - Режим доступу : http://zakon2.rada.gov.ua/laws/show/505-2014-\%D0\%BF.

7. Про визначення районів проведення антитерористичної операції і терміни її проведення : Наказ СБУ № 33/6/а від 7 жовтня 2014 р. [Електронний ресурс]. - Режим доступу : http://n.dt-kt.com/?p=339. 
Коробка Ирина, слушатель магистратуры спеииальности "Государственная служба" Донецкого государственного университета управления, заместитель начальника отдела бухгалтерского учета Мариупольского городского совета

Павлюк Валерий, кандидат наук по государственному управлению, доцент, доцент кафедры государственного управления и управления образованием Киевского университета им. Бориса Гринченко, г. Киев

\title{
ОРГАНИЗАЦИОННО-ПРАВОВЫЕ ОСНОВЫ СОЦИАЛЬНОЙ ЗАЩИТЫ ПЕРЕСЕЛЕНЦЕВ (ВНУТРЕННЕ ПЕРЕМЕЩЕННЫХ ЛИЦ) КАК ОСНОВА РЕАЛИЗАЦИИ СОЦИАЛЬНОЙ ПОЛИТИКИ ГОСУДАРСТВА
}

\begin{abstract}
В статье проведен анализ новых тенденций в социальной политике, направленных на поддержку внутренних переселенцев в Украине. Уточняются минимальные стандарты социальной помощи для данной категории граждан и определяются основные принципы социальной поддержки. Рассмотрены сущность социальной политики при оказании адресной помощи и содержание понятий "внутренне перемещенное лицо", "адресная помощь". Показана роль и направленность государственной социальной поддержки внутренне перемещенным лицам.
\end{abstract}

Ключевые слова: социальная политика; внутренне перемещенное лицо; адресная помощь.

Korobka Iryna,

undergraduate of Civil Service, Donetsk State University of Management,

Deputy Head of Accounting Department, Mariupol City Council

Pavliuk Valerii,

PhD in Public Administration, Associate Professor,

Borys Grinchenko Kyiv University

\section{ORGANIZATIONAL AND LEGAL PRINCIPLES OF SOCIAL PROTECTION OF DISPLACED PERSONS (INTERNALLY DISPLACED PERSONS) AS A BASIS FOR IMPLEMENTATION OF STATE SOCIAL POLICY}

The article analyzes the emerging trends of social policies to support internal migrants in Ukraine. The paper specifies the minimum standards of social care for this category of citizens and defines the basic principles of social support. The research explores the essence of social policy in the provision of targeted assistance and the meaning of "internally displaced person" and "targeted assistance". The article depicts the role and relevance of state social support for displaced individuals.

Keywords: social policy; internally displaced persons; targeted assistance.

() Коробка Ірина, Павлюк Валерій

Надійшла до редакції 29.04.2015 